\title{
Audiovisual Translation and Multilingualism
}

\section{B. O. Pliushch}

Assistant Professor, Taras Shevchenko National University of Kyiv, Kyiv, Ukraine

Corresponding author. E-mail: danapliushch@outlook.com

Paper received 27.08.21; Accepted for publication 14.09.21.

\section{https://doi.org/10.31174/SEND-Ph2021-257IX75-13}

Abstract. The article scrutinizes the audiovisual translation of internationally renown live-action hit American TV shows and series, that contain multilingualism within the framework of story development or character depiction. It analyses their dubbed versions in Ukrainian and Russian in terms of challenges multilingualism represents for a translation.

Keywords: translation, audiovisual translation, multilingualism, dubbing, live-action, TV show.

In audiovisual translation of live-action movies or TV shows multilingualism can present both a challenge and an opportunity for a translator. Multilingualism is widely understood as the use of more than two languages by any speaker/-s, which mirrors diversity of the modern globalized world. Translation handles diversity by its nature and the aim of this article is to consider different multilingual translation situations within the framework of audiovisual products distribution. The illustrative material for the study comprises such hit American TV shows as "The Good Wife", "Sopranos", "The Big Bang Theory" and "30 Rock" and their dubbed translations into Ukrainian and Russian.

In his book "Is that a Fish in Your Ear?" D. Bellos argues that "one of the truth of translation - one of the truth that translation teaches - is that everything is effable" [1:p.156]. He concludes by proclaiming translation to be "the enemy of the ineffable" because "it causes it to cease to exist" [1:p.159]. Audiovisual translation in particular showcases this idea since, as defined by F. Chaume, "an audiovisual text is a semiotic construct comprising several signifying codes that operate simultaneously in the production of meaning" [2: p.18]. Indeed, in audiovisual translation situation the audience has a synchronized contact with both the original and the translation product and thus can immediately notice any incongruity or incoherency on the side of the latter. J. Neves calls it "the extra stress" of the audiovisual translation and offers such a comparison of AVT with any other translation: "Whereas in written translation fidelity lies in two extreme points, the source-text or the targettext, in audiovisual translation fidelity is particularly due to an audience that, like the receiver of simultaneous interpretation, is in need of communicative effectiveness, rather than in search of artistic effect -as is the case in literary translation- or of exact equivalence -as happens with technical translation." [7: p.135] The requirement of communicative effectiveness is even more at stake if a live-action movie also happens to be multilingual (or even bilingual). According to J. D. Cintas, "the film industry is presenting viewers with more and more productions where several languages are spoken and different cultures are represented [...] as a reflection of reality" [3: p.218]. In his article on multilingual films and audiovisual translation Cintas supports the idea of dubbing being an "impossible translational strategy" [3: p.230] in terms of saving the film spirit and showcases his standpoint by analyzing audiovisual translations of Vicky Cristina Barcelona (2008) into Spanish, Catalan, German, Italian etc. In case of the Ukrainian film market, the status quo of the audiovisual translation modes employed is similar to Spain, Germany, France etc., that is dubbing is predominant. Moreover, the majority of population is bilingual and watches dubbed versions of movies and TV shows in both Ukrainian and Russian. Thus, for a Ukrainian viewer watching any foreign movie or series can be ascribed to a potentially multilingual mode, i.e. a multilingual movie dubbed in Russian etc.

X. Martínez describes dubbing as a "highly complex" process and states that "it is virtually inevitable that the translation initially delivered by the translator will undergo modifications. Indeed, audiovisual translation is probably the discipline in which the text undergoes most change from start to finish. All the stages of the process involve manipulation to some extent of the text submitted by the translator.[6:p. 5]. Due to this fact, the article focuses on the target language product version and its aim is to consider the correlation of the original and the translated audiovisual product within the framework of multilingual or polyglot TV productions.

One of the most internationally renown legal and political live-action TV shows of the last decade is "The Good Wife" that aired on CBS from September 22, 2009, to May 8, 2016. It centers on Alicia Florrick (masterfully portrayed by Julianna Margulies), "the wife of the Cook County State's Attorney, who returns to her career in law after the events of a public sex and political corruption scandal involving her husband" [9] and it is also considered to be "a show about the doubts that plague all systems of law and morality" [8]. The show has become an international success and was even remade by many countries such as Ireland, South Korea, Russia etc. "The Good Wife has an uncanny ability to weave [...] characters into the plot, making them feel integral to the story line and familiar, even when we don't see them that often" [5]. Since the series is concerned with legal and political affairs, it very often depicts multicultural and multilingual settings or characters etc. For example, in Episode 20 ("Foreign Affairs") of season 2 Lockhart Gardner is forced to work with Fred Thompson and the Venezuelan government on an oil case and one of the turning points in negotiating the contract is linguistic, that is the potential mistranslation of the Spanish word exito into English (as an exit), which the lawyers use to their own benefit.

a. Alicia: Mr. Francis, the contracts with our client were executed in both Spanish and English; is that correct? 


\section{FrancisIt is.}

Alicia: You speak Spanish, don't you, sir?

Francis: I do, fluently.

Alicia: Um, what does the word" éxito" mean?

Francis: It means "success."

Alicia: And yet it is often mistranslated as "exit," isn't it? And "exit" is sometimes mistranslated as "éxito." Probably because both words sound so alike.

Lawyer: Thank you, Rosetta Stone. What do you have? Alicia: Here, in the U.S. copy, it reads "exit strategy." And here, in the supposedly identical Spanish copy, "exit strategy" is translated as "estrategia de éxito"... "success strategy"

Francis:That is such utter b...!

Alicia: The delivery side-letter is now void because our client never agreed to the terms of your "exit" delivery $\underline{\text { date. }}$.

The illustrated above pre-trial oral examination (example a.) is based on Spanish and English mistranslations or, the so-called, false friends of the translator. The depicted precedent is typical for the series since one of the reasons for its international success is the authenticity in terms of reflecting the actual American reality: "In the U.S., 13 percent of the population speaks Spanish at home, earning it the title of the most common non-English language spoken. The U.S. also has the 2nd largest population of Spanish speakers in the world (Mexico has the largest)." [10] Thus, Spanish and Spanish speakers have a stake in American politics and business, which is clearly what is being showed in the abovementioned episode of the show. However, due to the Spanish language being at the core of the winning argument and thus creating an additional challenge for the translator, in Russian (example a. a.) the subject of the examination has slightly changed its course:

а. а. Алисия: Мистер Френсис, контракт с нашим клиентом был оформлен на испанском и английском, это так?

Френсис: Да.

Алисия: Вы ведь говорите по-испански, сер?

Френсис: Да, бегло.

Алисия: Что означает слово éxito?

Френсис: Оно означает успех.

Алисия: Его часто неправильно переводят как вblход, а выхход иногда неправильно переводят как éxito. Возможно потому, что эти два слова похоже звучат.

Адвокат: Cпасибо, Rosetta Stone. И что же?

Алисия: В американской копии стоит "условия расторжения”, a здесь, в якобы идентичной испанской копии условия расторжения переведено как estrategia de exito, то есть условие успеха.

Френсис: Да это полная...

Алисия: Дополнение $\kappa$ контракту больше не действительно, потому что наш клиент не принимал ваших условий успеха.

As illustrated in the example above, the last argument about the delivery side-letter being void is hard to grasp since Alicia is suddenly talking about her client "not accepting the conditions of success". That is not a coincidence that it doesn't make any sense since that is the exact opposite to what has happened - the client has signed the Spanish copy of the document, agreeing to estrategia de éxito (conditions of success) but never agreeing to estrategia de salida (exit conditions/ strategy). The translator probably struggled with Spanish and although the translation shows the attempt to follow the original as closely as possible the incoherence of the dialogue became unavoidable due to the failure to follow the logic of reasoning. This is a typical result of multilingualism creating an issue in audiovisual translation since the lack of translator's familiarity with the other language/-s used in the audiovisual product can result in incoherency of the dubbed version.

Very often multilingualism in live-action films and series is a part of character depiction, which is when it becomes critically important to preserve both the meaning and the multilingualism in the dubbed versions. Consider the following example from the international hit American TV sitcom "The Big Bang Theory", which aired on CBS from September 24, 2007 to May 16, 2019 and is considered to be "the longest-running multicamera comedy in TV history" [4] In the Episode 11 ("The Maternal Congruence") of Season 3 Sheldon Cooper is trying to comfort his friend Leonard, who is depressed after having learned that his parents are getting a divorce. Sheldon diagnoses him with a Jungian crises and continues by adhering to a particular German notion:

b. Leonard: Thank you, that's very comforting.

Sheldon: That's not the comforting part.

Leonard: It's not?

Sheldon: No, no. The comforting part is that the Germans have a term for what you're feeling. Weltschmerz. It means the depression that arises from comparing the world as it is to a hypothetical, idealized world.

Leonard: You're right, I do feel better.

Sheldon: Well, the Germans have always been a comforting people [...]

Here is how the same conversation sounds in Ukrainian TV version:

b. а. Леонард Дякую, ие дуже втімає.

Шелдон Це не заспокійлива частина.

Леонард $\mathrm{Hi}$ ?

Шелдон Ні. Заспокійлива частина полягає у тому, щуо у німиів є термін для того, щуо ти зараз відчуваєш - Weltschmerz - ие депресія, яка виникає внаслідок порівняння реального світу з гіпотетичним ідеалізованим.

Леонард Твоя правда. Мені краще.

Шелдон Німиі завжди добре заспокоювали.

Sheldon uses German words and phrases very often throughout the series, which presupposes his proficiency in the language. In Ukrainian he also speaks German, that is, as in the example above, the German expressions are retained in the dubbed version. In Russian the same strategy was used to preserve all the German words and phrases Sheldon occasionally uses throughout the series. However, in Episode 14 of season 5 it gets more obvious for the viewer that Sheldon is not that proficient in German. He is filming an episode of "Fun with Flags" in German and his girlfriend Amy is helping him in trying to attract more interest to the program:

c. Sheldon: Guten Tag, das Youtube. Ich bin ein Bavarian.

Amy: Und ich bin eine Pretzel. 
Sheldon: Und dis is Sheldon Cooper Presents: Fun ... Amy: mit...

Sheldon: Flags!

A German speaker would never use an article das in front of Youtube. Bavarian and Pretzel are English words with correspondences in German - Bayer and Brezel, respectively. Hence, the hilariousness of the episode is based on mixing English and German. The "mistakes" make the episode funny especially for multilingual viewers, who speak both English and German. Let's consider how the dialogue sounds in Ukrainian and Russian:

c. а. Шелдон: Guten Tag, Youtube! Ich bin Баварецьь! Eмі: Und ich bin Крендель.

Шелдон: Und das ist шоу Шелдона Купера:

Веселощі..

Eмі: $3 \ldots$

Шелдон: Прапорами!

c. b. Шелдон: Guten Tag, das Youtube! Ich bin ein

Бавариан!

Эми: Und ich bin ein Преиель!

Шелдон: Und this is Занимательные флаги...

Эми: mit...

Шелдон: Шелдон Купер!

In Ukrainian Sheldon and Amy speak a mixture of German and Ukrainian (Баварець - Bavarian). However, Ukrainian крендель doesn't match a German Brezel baked pastry made from dough, usually salty - since it's cookie, which can be sweet. In Russian Sheldon and Amy are speaking German, Russian and English, since Бавариан and Преиель are English words. Thus, the translator adhered to calque in attempt to convey the multilingual mode of the episode. Both versions can be considered funny, thus, the pragmatic aspect is fulfilled. However, Russian dubbing can be confusing to those viewers, who have no proficiency in either English, or German. The examples b., b.a, c., c.a, c.b. illustrate the instances, where multilingualism in live-action audiovisual products can not be omitted since it is used not just for character development but for creating humorous effect, which in the case of any sitcom is a bedrock of the genre. In most cases, dubbed versions mirror the original by introducing another language in the soundtrack and the translator's obvious lack of proficiency with that language leads to certain incoherencies or difficulties in following the logical thread of the dialogues.

To sum up, multilingualism in live-action TV shows and series is one of the biggest challenges in audiovisual translation, especially dubbing. At the same time, a multilingual audiovisual product is usually the one with the highest international ratings and global visibility, which makes any multilingual production one of the most aspiring projects for a translation and a high-stake one for a translator.

\section{REFERENCES}

1. Bellos D. Is that a Fish in Your Ear? The Amazing Adventure of Translation / D. Bellos. - London: Penguin Books, 2012. 390 p.;

2. Chaume F. Film Studies and Translation Studies: Two Disciplines at Stake in Audiovisual Translation / F. Chaume // Meta. - Montreal: Les Presses de l'Université de Montréal, 2004. - Vol.49, Iss.1, Avril. - P. 12-24.;

3. Diaz Cintas J. Dealing with Multilingual Films in Audiovisual Translation / J. Diaz Cintas // Translation. Sprachvariation. Mehrsprachigkeit. Festschrift für Lew Zybatow zum 60. Geburtstag (Herausgegeben von W. Pöckl, I. Ohnheiser, P. Sandrini). - Frankfurt am Main: Peterlang, 2011. - P.216233.;

4. Goldberg L. "The Big Bang Theory": Why Jim Parsons Walked away from one of TV's biggest Hits / L.Goldberg // The Hollywood Reporter, May15, 2019. https://www.hollywoodreporter.com/tv/tv-news/big-bangtheory-why-jim-parsons-walked-away-one-tvs-biggest-hits1209940/;

5. Hoffman L. The Best and Worst of The Good Wife/ L. Hoffman // Vulture, May 3, 2016. -

6. Martínez X. Film dubbing. Its process and translation/ X. Martínez // Topics in Audiovisual translation (ed. By P. Orero). - Amsterdam/ Philadelphia: John Benjamins Publishing Company, 2004 - P. 3-7.;

7. Neves J. Language awereness through training in subtitling / J. Neves // Topics in Audiovisual translation (ed. By P. Orero). - Amsterdam/ Philadelphia: John Benjamins Publishing Company, 2004 - P.127-140;

8. Rothman J. What was "The Good Wife" really about? / J. Rothman // The New Yorker, May 19, 2016. https://www.newyorker.com/culture/cultural-comment/whatwas-the-good-wife-really-about;

9. The Good Wife. https://en.wikipedia.org/wiki/The_Good_Wife\#Reception;

10. Thompson S. The U.S. has the second-largest population of Spanish speakers - How to equip your brand to serve them / S. Thompson // Forbes, May 27, 2021. https://www.forbes.com/sites/soniathompson/2021/05/27/theus-has-the-second-largest-population-of-spanish-speakershow-to-equip-your-brand-to-serve-them/?sh=2df93976793a. 